\title{
Listening Tests Information For The Ninth Grade Of Private Junior High Schools
}

\author{
Yustika Ilmiawati ${ }^{1}$;ri Susilowati ${ }^{2}$ Rahayu Retnaningsih ${ }^{3 *}$ Moh. Rusnoto Susanto ${ }^{4}$ \\ rahayu@ustjogja.ac.id \\ Universitas Sarjanawiyata Tamansiswa
}

\begin{abstract}
The purpose of this study was to find whether private schools have guideline books in listening tests for the requirement of graduation in the ninth grade. Participants were twenty-six schools. The questionnaires gave to the teachers and their students. The results indicated that each school has a listening test for the requirement of graduation, but there is no guidance among the schools. It was proved that the teachers need the listening test handbook to equate the listening test for the ninth grade. This research is proper to help the teachers develop their knowledge to equate perception to obtain a handbook for a listening test that can be used for the whole school.
\end{abstract}

Keywords: Listening Test, Handbook, Private School.

\section{Background}

In learning a second language especially English, four essential skills should be learned to have reasonable competence in learning a language. They are speaking, listening, writing and reading. At the early stage, children usually learn the first language by listening to people around them then learn how to speak. Reading and writing become the last skills to be learned.

The English teaching and learning process in Junior High Schools is aimed at developing the student's competence in English to achieve the level of functional literacy. It is also aimed at developing the students' understanding and competence in a global society.

The Junior High School students have to master the four skills of English, to listen, to read, to speak, and writing. In daily life, people listen more than speak, read or write. It means that listening is one of the essential skills that should be mastered because it helps students to learn and improve other English skills.

The ninth-grade students of Junior High School have to master listening skills so that they can understand some instructions from their teacher in the English teaching and learning process and they could respond to them well. Even more, in the ninth grade, students must carry out the English language practice exam as part of the school exam that determines graduation.

However, it is not easy for English teachers to teach the students to reach the primary goal. It can be seen from the scores of their final exam. Students are unable to listen to the English text well, or sometimes they fail to write what they hear. Nearby, English teachers have no guidelines books to carry out practice exams. Teachers in each school have their practice exams questions by themselves. The last problem is the crucial problem in the listening tests because it is a part of the practice exam that determines graduation.

\section{Literature Review}


Most students are expected to understand what people say or convey in a conversation. Many media currently use English, both through television, radio, cinema, tape, and other media. The way people speak is often significantly different from the way they write and listen. This is why listening is essential for the students to learn. One of the primary sources of listening lessons for students is the voice of their teacher. There is nothing wrong or wrong with that, but, there are some regional variations that will appear during the delivery of English. In the teaching and learning process, the use of native speakers is very supportive of students in recognizing words and sentences that are heard, so that students understand the meaning of the word or sentence. Also, students are also expected to be able to hear well, whether it is about general information or understanding of the story or interacting in a social conversation and responses[1].

For the ninth grade students of junior high school, listening is one of the four skills contained in the syllabus and necessary competencies so that it should be obliged to be carried out in the student practice exam as part of the graduation exam. The listening test meant here is a test of listening ability for the ninth grade students of junior high school which is part of the practical examination as part of graduation requirements. Richards[2], “....we might ask students to put a set of the picture in order as they read or listen to a story, or complete a phone message form (for a listening task) ...". It means that as a teacher, we could give students the direct test. We ask students to use language or how the language itself works. Teachers could know how far the students progress during the learning process. Teachers did not do the listening tests because of some reasons. The main reason, no media or handbook support the listening tests during the examination.

Nation[3] in his book state that the tests should be to allow the students to show us what they know and can do, not what they do not know and can't do. It means, if possible, it is a good idea to give the test out with students in the same level as the one it is designed for, so it will highlight any items which are unclear. Therefore, it will be the next teacher evaluation material in designing the listening tests material and the right course book or handbook that can be used in listening for students.

\section{Methodology}

The classroom observation conducted in Private Junior High Schools for the ninth grade's teachers. There are 49 private Junior High Schools. The researchers took 15 schools as the samples. These schools are chosen as the participant of the research based on its ideal condition and the average and heterogeneous academic achievement.

The research data took from observations, questionnaires, an interview[4]. The teacher of the ninth grade gave the optional questionnaire about the listening tests material. This information was useful whether the design listening tests material by the standard competence and basic competence for the practice exam as part of graduation requirements.

In doing the research, the instruments used to collect the data. In this research, the data took from the listening tests process in practice examination of the ninth grade. The instruments used questionnaires and field notes.

The data analysis used qualitatively. According to Miles, Huberman[5], qualitative data analysis involve three kinds of concurrent flows of activity; data condensation, data display, and conclusion/drawing/verification.

\section{Findings and Discussion}


During the observation, it was found that teachers in the grade nine carried out teaching and learning activities for four skills (reading, speaking, listening and writing) by the syllabus and essential competencies. In the implementation of the grade nine practice exams which are part of the requirements for graduation exams, almost all teachers did not practice the four skills. Some teachers only take reading and writing, and some take speaking only. Most of the teachers, aside from a listening test. Various opinions expressed by the teachers regarding the absence of listening tests included:

1. There is no language laboratory in each school.

2. There is no handbook or material guide book for the implementation of the listening test in every school.

This is the primary concern of the researchers in observing whether there is a listening test in the ninth grade Junior High School practice exams as part of the graduation exam requirements so that the results above are obtained.

Table 1.

Data of Requirement Practice Exams

\begin{tabular}{|c|c|c|c|c|c|}
\hline No & School & Listening & Reading & Writing & Speaking \\
\hline 1 & SMP Muhamma diyah 8 & - & $\sqrt{ }$ & $\sqrt{ }$ & $\sqrt{ }$ \\
\hline 2 & SMP Bopkri 10 & - & $\sqrt{ }$ & $\sqrt{ }$ & $\sqrt{ }$ \\
\hline 3 & SMP Budya Wacana & $\sqrt{1}$ & $\sqrt{ }$ & $\sqrt{ }$ & $\sqrt{ }$ \\
\hline 4 & SMP Kanisius Gayam & - & $\sqrt{ }$ & $\sqrt{ }$ & $\sqrt{ }$ \\
\hline 5 & SMP Perak & $\sqrt{1}$ & $\sqrt{1}$ & $\sqrt{ }$ & $\sqrt{1}$ \\
\hline 6 & SMP Perintis & - & $\sqrt{1}$ & $\sqrt{1}$ & - \\
\hline 7 & SMP Piri 2 & $\sqrt{1}$ & $\sqrt{ }$ & $\sqrt{1}$ & $\sqrt{ }$ \\
\hline 8 & SMP Budi Luhur & - & $\sqrt{ }$ & $\sqrt{ }$ & - \\
\hline 9 & $\begin{array}{l}\text { SMP Taman Dewasa Ibu } \\
\text { Pawiyatan Kumendaman }\end{array}$ & - & $\sqrt{ }$ & $\sqrt{ }$ & $\sqrt{ }$ \\
\hline 10 & $\begin{array}{l}\text { SMP Pembangunan } \\
\text { Maarif }\end{array}$ & $\sqrt{ }$ & $\sqrt{ }$ & $\sqrt{ }$ & $\sqrt{ }$ \\
\hline 11 & SMP 17 "1" & - & $\sqrt{1}$ & $\sqrt{ }$ & $\sqrt{ }$ \\
\hline 12 & SMP $17 " 2 "$ & - & $\sqrt{ }$ & $\sqrt{ }$ & $\sqrt{ }$ \\
\hline 13 & SMP Gotong Royong & - & $\sqrt{1}$ & $\sqrt{1}$ & $\sqrt{1}$ \\
\hline 14 & SMP IT BIAS & $\sqrt{1}$ & $\sqrt{ }$ & $\sqrt{ }$ & $\sqrt{1}$ \\
\hline 15 & SMP Muhamma diyah 9 & $\sqrt{ }$ & $\sqrt{ }$ & $\sqrt{ }$ & $\sqrt{1}$ \\
\hline
\end{tabular}




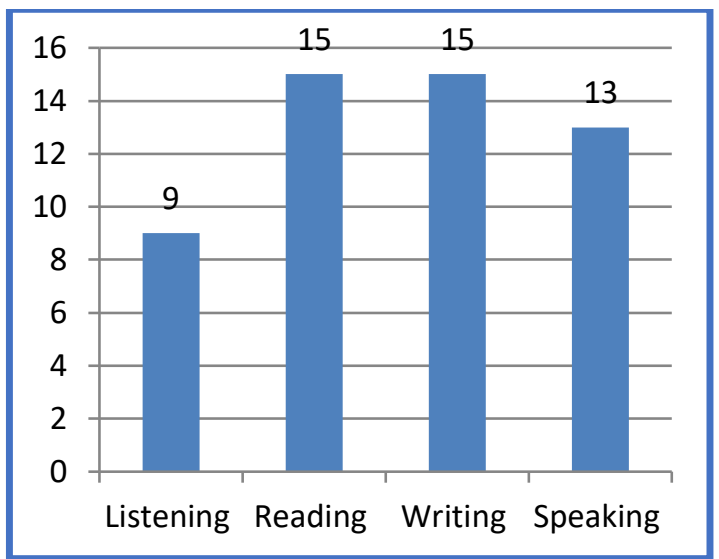

\section{Conclusion}

From the explanation above, we conclude that: Not all of the English teachers using four skills as the practical examination in the ninth grade of Junior High School. The teachers have no guidelines book for the final examination to the ninth grade. The teachers make the listening tests material by them based on basic competence. Therefore, each school has their regulation in giving listening tests for their students.

\section{References}

[1] H. D. Brown, Teaching by Principles: An Interactive Approach to Language Pedagogy. New York: Longman, 2001.

[2] J. Richards, Teaching Listening and Speaking from Theory to Practice. New York: Cambridge University Press, 2008.

[3] J. Nation, I.S.P. \& Newton, Teaching ESL/ EFL Listening and Speaking. London: Routladge, 2009.

[4] L. J. Moleong, Metode Penelitian Kualitataif. Bandung: P.T. Remaja Rosdakarya, 2010.

[5] A. M. Miles, M.B. and Huberman, Qualitative Data Analysis, 2nd ed. Newbury Park, CA: Sage, 2014. 